\title{
Artikel Ulas Balik Urgensi dan Mekanisme Biosintesis Metabolit Sekunder Mikroba Laut
}

\author{
Risa Nofiani \\ Jurusan Kimia, FMIPA, Universitas Tanjungpura, Jalan Ahmad Yani, Pontianak, 78124 \\ Tel.+62561736439, E-mail:rnofiani@yahoo.com
}

Diterima 27-08-2007 Disetujui 17-03-2008

\begin{abstract}
Marine microorganism is one of biologically active potential resources of secondary metabolites. Its potency are so promising that the knowledge of how its secondary metabolite occured need to be studied and collected. Those knowledges will enable further study is improving secondary metabolite production in the laboratory. In nature, secondary metabolites synthesis occur when there are effect of both biotic and abiotic factors such as sea water and microbe symbiosis with other living materials. When this is explained in metabolic pathways, secondary metabolite synthesis affected by available nutrient and regulated by autoinducer molecules through quorum sensing mechanism
\end{abstract}

Keywords: autoinducer, marine microorganism, quorum-sensing, secondary metabolite, symbiotic

\section{PENDAHULUAN}

Laut merupakan salah satu sumber kekayaan biologi dan kimia. Salah satu sumber kekayaan biologi dan kimia dapat diperoleh dari bakteri laut. Meskipun bakteri laut menyusun sebagian kecil mahluk hidup laut tetapi satu sel bakteri laut mengandung ribuan senyawa kimia yang berpotensi untuk obat-obatan, suplement nutrisi, kosmetik, agrokimia, probe kimia dan enzim. Umumnya senyawa kimia potensial ini berasal dari metabolit sekunder mikroba.

Metabolit diklasifikasikan menjadi dua, yaitu metabolit primer dan metabolit sekunder. Metabolit primer yang dibentuk dalam jumlah terbatas adalah penting untuk pertumbuhan dan kehidupan mahluk hidup. Metabolit sekunder tidak digunakan untuk pertumbuhan dan dibentuk dari metabolit primer pada kondisi stress. Contoh metabolit sekunder adalah antibiotik, pigmen, toksin, efektor kompetisi ekologi dan simbiosis, feromon, inhibitor enzim, agen immunomodulasi, reseptor antagonis dan agonis, pestisida, agen antitumor, dan promotor pertumbuhan binatang dan tumbuhan.

Ada beberapa hipotesis tentang fungsi metabolit sekunder bagi produsen metabolit sekunder, misalnya dalam mempertahankan hidup dari bakteri, fungi, insekta, dan binatang melalui produksi antibiotik dan anti kotor (antifouling) (Gudbjarnason 1999). Selain itu, metabolit sekunder berperan juga dalam memperbaiki kehidupan mikroba penghasil metabolit sekunder ketika berkompetisi dengan spesies lain (Tabarez 2005). Ada 5 alasan yang memperkuat hal tersebut (Tabarez 2005). Pertama, metabolit sekunder beraksi sebagai mekanisme pertahanan alternatif sehingga organisme yang kekurangan sistem imun akan menghasilkan metabolit sekunder yang banyak dan bermacammacam. Kedua, metabolit sekunder memiliki struktur dan mekanisme kerja yang mantap (sophisticated) serta jalur metabolismenya komplek dan mahal secara energetika. Ketiga, metabolit sekunder beraksi jika ada kompetisi dengan mikroba, tanaman, atau binatang. Keempat, metabolit sekunder dihasilkan oleh sekelompok gen biosintesis. Kelima, produksi metabolit sekunder dengan aktivitas antibiotik biasanya diiringi dengan sporulasi dan terjadi pada sel mikroba yang sensitif dengan mikroba, tumbuhan, atau binatang. Umumnya mikroba sensitif ini membutuhkan perlindungan khusus ketika nutrisinya mulai habis.

Pembentukan metabolit sekunder diatur oleh nutrisi, penurunan kecepatan pertumbuhan, feedback control, inaktivasi enzim, dan induksi enzim. Keterbatasan nutrisi dan penurunan kecepatan pertumbuhan akan menghasilkan sinyal yang mempunyai efek regulasi sehingga menyebabkan diferensiasi kimia (metabolit sekunder) dan diferensiasi morfologi (morfogenesis) (Demain 1998). Signal ini adalah suatu induser dengan berat molekul rendah yang berkerja sebagai kontrol negatip sehingga pada keadaan normal (pertumbuhan cepat dan cukup nutrisi) 
mencegah pembentukan metabolit sekunder dan morfogenesis. Tidak seperti metabolit primer, jalur metabolit sekunder belum banyak dimengerti. Oleh karena itu, pada artikel ulas balik ini akan dicoba membahas tentang terjadinya metabolit sekunder di alam dan faktor-faktor yang mempengaruhi mekanisme biosintesis metabolit sekunder mikroba laut.

Biosintesis metabolit sekunder mikroba laut di alam. Hasil eksplorasi metabolit sekunder selama ini menunjukkan bahwa bakteri laut merupakan salah satu sumber potensial metabolit sekunder. Berdasarkan cara hidupnya, bakteri penghasil metabolit sekunder dapat berasal dari bakteri yang hidup bebas, bakteri laut yang terdapat pada sedimen, bakteri yang berasosiasi dengan permukaan alga, atau bakteri yang berasosiasi dengan invertebrata (Burgess et al, 1999). Berdasarkan hasil penelitian terdahulu, umumnya bakteri yang hidup dengan cara berasosiasi dengan mahluk hidup laut menunjukkan potensi besar dalam sekresi metabolit sekunder dengan sifat antibakteri (Burgess et al, 1999; Amstrong et al, 2001; Yan et al, 2003). Bakteri yang hidup berikatan dengan partikel tertentu menghasilkan metabolit sekunder 5-10 kali lebih tinggi dibandingkan dengan bakteri yang hidup bebas (Long 2001). Contoh bakteri penghasil metabolit sekunder laut adalah Actinopolyspora species AH1 diperoleh dari sedimen laut dan menunjukkan aktivitas antimikroba (Kokare et al, 2003). Bakteri epibiotik yang diambil dari Petrosia ficiformis berkemampuan menghambat pertumbuhan bakteri laut lain secara in vitro (Chelossi et al, 2004). Pseudoalteromonas piscicidayang berasosiasi dengan spons Hymeniacidon perleve menghasilkan senyawa norharman (suatu alkaloid betakarbolin) yang memiliki aktivitas antimikroba ( Zheng et al, 2005).

Umumnya struktur kimia produk laut sering berbeda dari metabolit sekunder daratan terutama pada halogenasi dengan bromin dan atau klorin (Gudbjarnason 1999). Perbedaan ini dipengaruhi oleh lingkungan laut yang unik. Menurut Okami (1982), ada 3 fakta yang membuktikan bahwa lingkungan laut unik. Pertama, air laut mengandung bermacam-macam substansi yang aktif secara biologi seperti vitamin, dan banyak mikroorganisme laut barkemampuan untuk menghasilkan vitamin. Kedua, air laut mengandung agen inhibitor yang aktif untuk organisme. Beberapa faktor yang menggambarkan kenyataan ini adalah air laut mempunyai kemampuan menghambat bakteri gram positif, air laut dari alam lebih menghambat daripada air laut buatan, air laut yang telah diberi perlakuan panas menunjukkan pengurangan aktivitas inhibitor dibandingkan dengan air laut yang segar, aktivitas inhibitor air laut tidak disebabkan oleh faga atau salinitas tapi karena ada agen antibakteri dalam air laut. Ketiga, beberapa mikroorganisme yang diisolasi dari air laut menunjukkan aktivitas antibakteri.

Simbiosis antara mikroba dengan invertebrata menjadi suatu aturan yang digunakan mikroba dalam menghasilkan jenis metabolit sekunder apa yang akan dihasilkan (Thakur et al, 2003). Umumnya jenis metabolit sekunder yang dihasilkan mikroba dimanfaatkan oleh invertebrata laut untuk melawan serangan mahluk hidup lain. Berdasarkan hal di atas diperoleh suatu konsep baru yang menyatakan bahwa simbiosis yang menghasilkan metabolit sekunder dapat dipicu karena adanya halangan lingkungan biotik. Model yang digunakan untuk menjelaskan konsep ini adalah simbiosis bakteri dengan spons pada Gambar 1 (Muller et al, 2004). Mula-mula sel inang (spons) mensintesis

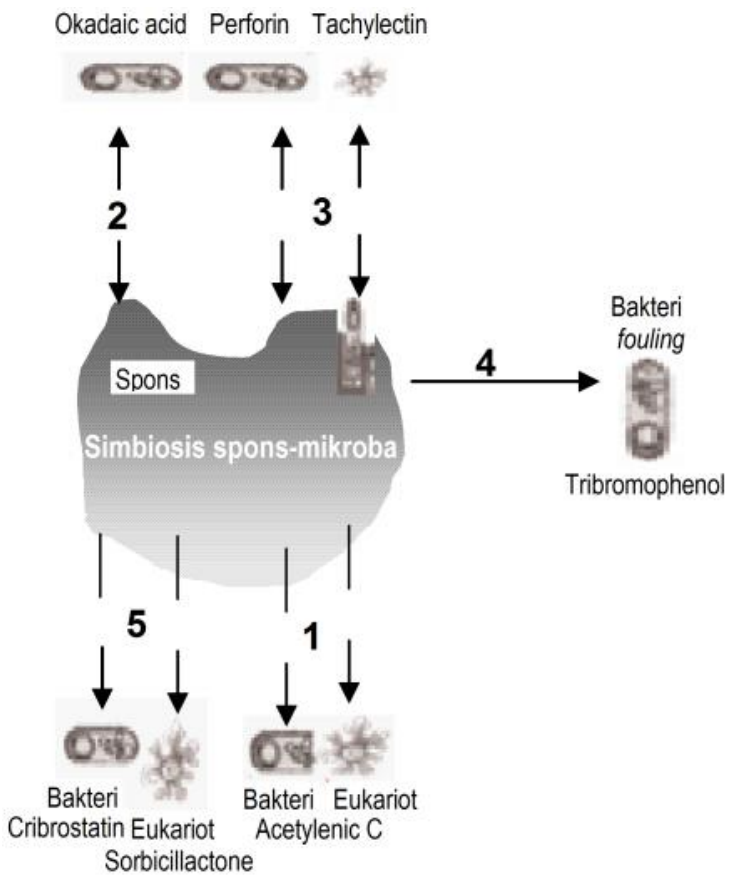

Gambar 1. Model Produksi Metabolit Sekunder melalui Simbiosis Spons dengan Mikroba (Muller et al., 2004) 1. Sel inang (spons) mensintesis senyawa bioaktif untuk melengkapi perlindungan melawan serangan mikroba/eukariot; 2. Mikroba berasosiasi dengan spons menghasilkan suatu metabolit sekunder yang berperan dalam sistem pertahanan spons; 3 . Perlindungan dengan sistem imun; 4. Perlindungan tidak langsung; 5. Simbiosis bakteri atau fungi menghasilkan metabolit sekunder. 
metabolit sekunder untuk melengkapi perlindungan melawan serangan mikroba atau eukariot (perlindungan langsung pertama), contoh senyawa asetilenat. Selain itu, spons dapat juga menghasilkan metabolit sekunder berupa protein yang dapat menahan pertumbuhan bakteri (perlindungan dengan sistem imun), contohnya adalah perforin (Thakur et al, 2003) dan tachylectin (Schroder et al, 2003). Secara fungsional, senyawa ini beraksi sebagai molekul pertahanan. Akibat adanya interaksi metabolit sekunder yang dihasilkan dengan bakteri yang berasosiasi dengan spons menyebabkan kemungkinan bakteri terinduksi untuk menghasilkan suatu metabolit sekunder. Metabolit sekunder yang dihasilkan memiliki bermacam-macam fungsi, misalnya berfungsi dalam sistem pertahanan sekaligus pengaktivasi jalur penting untuk pertahanan diri (aktivator metabolit). Contoh metabolit sekunder bakteri adalah asam okadaat (okadaic acid) yang dihasilkan oleh bakteri dalam spons Suberites domuncula. Asam okadaat berperan sebagai molekul pertahanan melawan serangan metazoa asing dan secara simultan merupakan modulasi positif jalur ini untuk memperbesar respon imun sel inang (Wiens et al, 2003). Bakteri yang hidup pada permukaan sel inang spons menghasilkan metabolit sekunder spesifik untuk melawan bakteri tertentu (perlindungan tidak langsung), contoh senyawa antifouling (Thakur et al, 2003) dan senyawa tribromophenol (Clare et al, 1999). Contoh metabolit sekunder yang dihasilkan akibat adanya simbiosis antara spons dengan bakteri atau fungi, bakteri atau fungi juga terinduksi untuk menghasilkan senyawa metabolit sekunder seperti cribrostatin atau sorbicillactone.

Selain mikroba bersimbiosis spons, juga bersimbiosis dengan alga seperti simbiosis alga hijau Enteromorpha linza dengan bakteri Flavobacterium spp. dan Cytophaga spp. (Shiba \& Taga 1980). E. linza menghasilkan produk ekstraselular yang diserap oleh Flavobacterium spp. dan Cytophaga spp. yang menyusun biofilm pada alga. Bakteri pigmen hijau Pseudoalteromonas tunicata yang juga membentuk biofilm dapat menghasilkan senyawa inhibitor spesifik target melawan bakteri, alga, fungi, dan larva invertebrata (Prochnow et al, 2004).

Biosintesis metabolit sekunder yang dipengaruhi oleh ketersediaan nutrisi tertentu. Metabolit primer dapat meningkatkan produksi metabolit sekunder. Pada mikroba laut, kondisi lingkungan dengan nutrisi terbatas menyebabkan penggunaan karbon oleh mikroba laut dalam metabolisme selular tidak digunakan untuk pertumbuhan sel melainkan karbon yang tersedia akan digunakan untuk produksi metabolit sekunder. Eksperimen Barry dan Wainwright (1997) membuktikan bahwa penambahan prekursor metabolit primer dapat meningkatkan metabolit sekunder. Induksi prekursor metabolit primer yang digunakan adalah \pm -ketoglutarat, 2-ketoglutarat, glukosa, dan oksaloasetat. Bakteri laut J292/97 diinokulasi dalam berbagai media yaitu Marine Broth Difco (MB), MB yang diencerkan 10X (MB 1:9), MB 1:9 yang disuplemen dengan $0,1 \% \pm$-ketoglutarat, MB 1:9 yang disuplemen dengan $0,1 \%^{2}$-ketoglutarat, MB 1:9 yang disuplemen dengan $0,1 \%$ glukosa, MB $1: 9$ yang disuplemen dengan $0,1 \%$ oksaloasetat. Media pertumbuhan yang disuplemen dengan prekursor siklus TCA (Tricarboxylic acid) yaitu \pm -ketoglutarat dan oksaloasetat akan menginduksi senyawa yang memiliki aktivitas antimikroba. Pseudomonas fluorescens HV37a mensintesis antibiotik dalam keberadaan glukosa (Gutterson et al, 1988). Selain itu media MB yang diencerkan 10x (MB 1:9) yang disuplemen dengan glukosa $0,1 \%$ dapat juga menginduksi senyawa antibakteri dari Alteromonas sp. K10 dan Bacillus sp. K11.

Nitrogen juga berperan dalam produksi metabolit sekunder mikroba. Pada kondisi nitrogen terbatas, ppGpp sintetase (RelA) yang berasosiasi dengan ribosom dibutuhkan untuk produksi antibiotik oleh Streptomyces coelicolor A3(2) (Chakraburtty \& Bibb 1997). Kondisi ini juga dibutuhkan untuk produksi cephamycin C oleh Streptomyces clavuligerus (Jin et al, 2004). Meskipun demikian mekanisme produksi antibiotik yang digerakkan oleh ppGpp ini belum jelas.

Biosintesis metabolit sekunder seperti antibiotik dipengaruhi juga oleh ketersediaan fosfat (Martin 2004). Umumnya produksi metabolit sekunder terjadi pada kondisi fosfat terbatas. Komponen yang berperan yaitu sistem PhoR-PhoP. PhoR adalah protein membran standar sensor kinase. PhoP adalah suatu protein anggota regulator respon terikat dengan DNA. PhoP berperan juga dalam mengontrol gen fosfatase alkalin (PhoP). Jika terjadi inaktivasi regulator respon PhoP atau delesi sistem PhoR-PhoP menyebabkan terjadinya ekspresi tinggi actinohordin dan undesilprodigosin pada 
S. coelicolor dan S. lividans. Usulan mekanisme Cascade berhubungan dengan efek negatif fosforilasi PhoP pada ekspresi AfsS ditunjukkan pada Gambar 2 (Martin 2004). Ekspresi gen act (actinorhodin) dan red (undesilprodigiosin) diregulasi oleh aktivator transkripsi spesifik, Actll-ORF4 dan RedD. Produksi Actll-ORF4 dan RedD diinduksi oleh AfsS. Ekspresi tinggi AfsS akan menyebabkan ekpresi tinggi Actll-ORF4 dan RedD sehingga terjadi juga ekspresi tinggi Act dan Red. AfsS diregulasi oleh sistem PhoR-PhoP. AfsS direpresi oleh sistem PhoR-PhoP jika PhoP dalam keadaan terfosforilasi (PhoP P).

Regulasi biosintesis metabolit sekunder dengan sistem quorum-sensing. Quorum-sensing adalah regulasi ekspresi gen yang tergantung pada densitas sel. Umumnya mekanisme quorum-sensing digunakan oleh bakteri gram negatip. Bakteri menghasilkan molekul sinyal yang mampu berdifusi keluar dan ke dalam sel. Molekul ini biasanya dikenal dengan nama autoinduser. Autoinduser yang ditemukan pada bakteri gram negatip adalah asilasi homoserin lakton (AHL). Model quorum-sensing ditunjukkan oleh simbiosis bakteri laut, Photobacterium fischeridengan ikan atau cumi-cumi pada Gambar 3 (Gonzalez \&

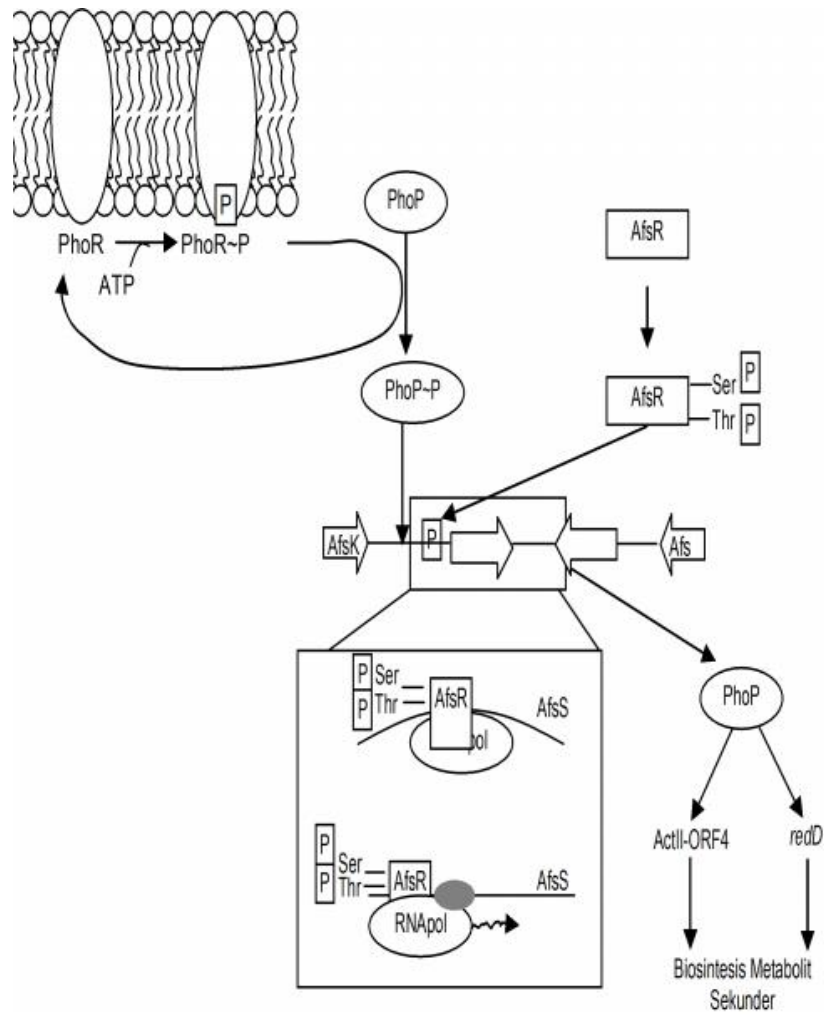

Gambar 2. Usulan mekanisme cascade fosfat mengontrol biosintesis actinohordin dan undecylprogiosin (Martin 2004)

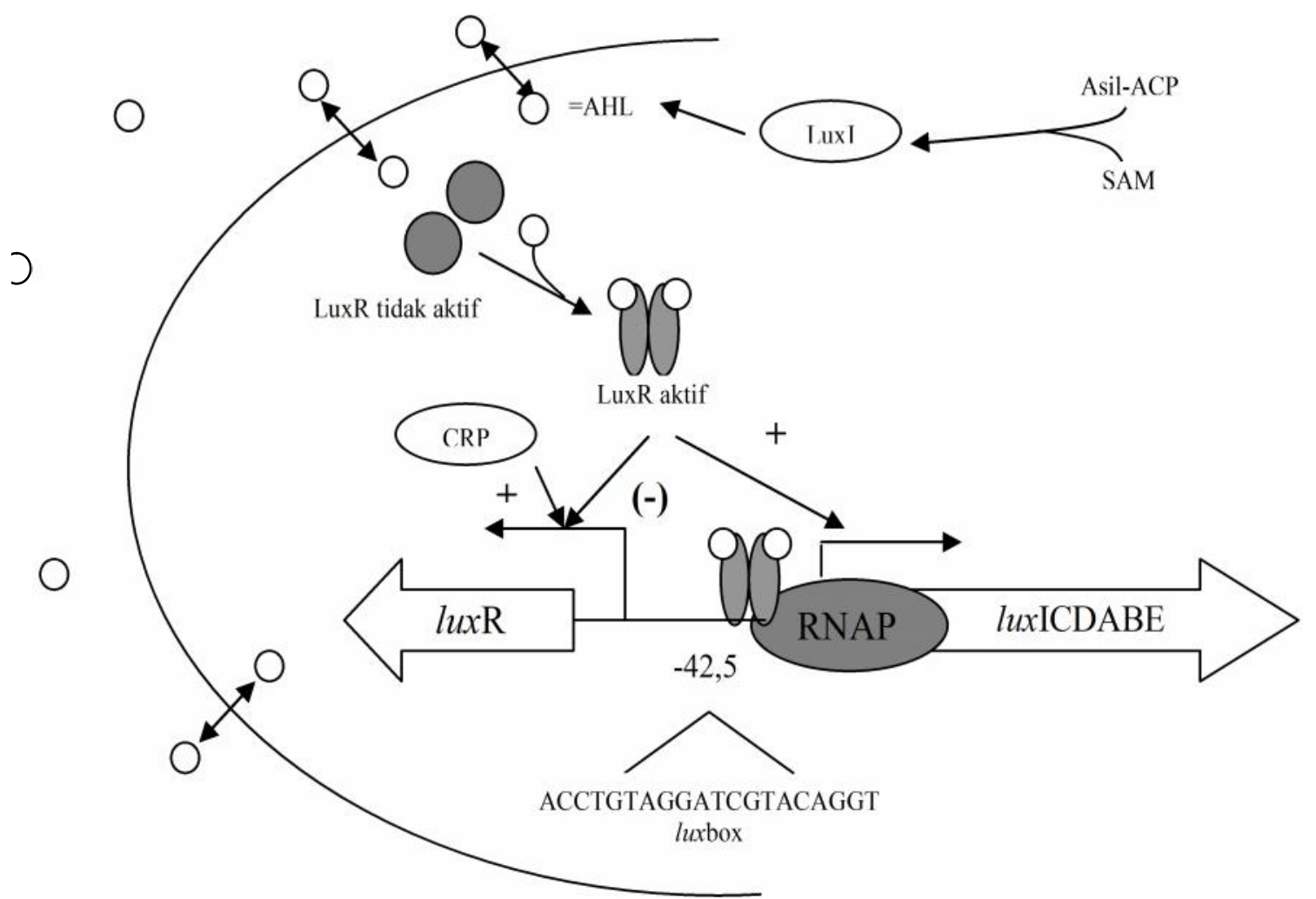

Gambar 3. Model Quorum-Sensing pada Simbiosis P. fischeri dengan ikan atau cumi (Gonzales and Martin 2004) 
(S-adenosilmetionin) dengan bantuan enzim AHL sintase yang dikode oleh gen Luxl. Peningkatan densitas sel menyebabkan akumulasi AHL yang selanjutnya menyebabkan LuxR aktif karena AHL akan berikatan dengan LuxR. LuxR yang aktif ini akan mengaktivasi ekspresi operon lux tetapi menghambat ekspresi gen luxR.

Pseudomonas fluoresescen NCIMB 10586 menghasilkan senyawa mupirocin. Ekspresi gen Mupirocin dari Pseudomonas fluoresescen NCIMB 10586 bergantung pada sistem regulator quorumsensing (El-Sayed et al, 2001). Gen yang mengode mupirocin adalah operon Mup. Asam amino MupR dan Mupl menunjukkan kemiripan dengan sistem regulator LasR/LasI dan LuxR/LuxI. MupR penting untuk mengativasi mupl dan operon mup. Selain sintesis mupirocin yang mengikuti sistem regulasi quorumsensing, produksi senyawa antibakteri dari bakteri Roseobacter 27-4 juga mengikuti regulasi quorumsensing (Buhn et al, 2005). Hal ini disebabkan karena senyawa ini terbentuk jika densitas sel tinggi.

Selain AHL, autoinduser yang lain adalah $\gamma$ butirolakton (butanolida). Contoh butanolida adalah faktor A (2-isokapriloil-3R-hidroksimetail- $\gamma$-butirolakton) Streptomyces griseus. Faktor A S. griseus diproduksi sebelum produksi streptomisin dan akan terhenti pada saat produksi streptomisin mencapai level maksimum (Horinouchi \& Beppu 1992). Faktor A menginduksi paling sedikit 10 protein pada level transkripsi. Satu diantaranya adalah streptomisin 6-fosfotransferase, suatu enzim yang berfungsi dalam biosintesis streptomisin dan dalam resistensinya terhadap streptomisin.

Induksi biosintesis metabolit sekunder mikroba di laboratorium. Ada beberapa hambatan yang ditemui dalam sintesis metabolit sekunder di laboratorium. Beberapa mikroba yang hidup bersimbiosis dengan mahluk hidup di laut sulit dikulturkan di laboratoium. Beberapa mikroba penghasil metabolit sekunder dapat juga kehilangan kapasitas menghasilkan metabolit sekunder setelah penyimpanan dalam waktu singkat (Tabarez 2005). Penyebab hal ini adalah tidak terpenuhinya kebutuhan nutrisi atau strain penghasil metabolit sekunder tidak berada dalam keadaan stres serta bisa juga disebabkan oleh lingkungan abiotik. Upaya yang dilakukan untuk mengatasi lingkungan abiotik adalah membuat kondisi pada saat kultivasi mirip dengan lingkungan aslinya misalnya dengan memodifikasi metode kultivasi konvensional. Bacillus licheniformis El-34-6 menghasilkan metabolit sekunder jika ditumbuhkan pada sebuah bioreaktor yang menggunakan membran semipermeabel. $B$. licheniformis El-34-6 tapi tidak menghasilkan metabolit sekunder jika ditumbuhkan pada kultur cair yang dikocok (Yan et al, 2003). Perbedaan tipe membran semipermeabel tidak menunjukkan hasil yang berbeda sehingga dapat disimpulkan bahwa komposisi kimia membran tidak mempengaruhi produksi senyawa antimikroba. Bacillus sp. yang diisolasi dari alga Palmaria palmate menghasilkan senyawa antimikroba dengan spektrum yang bervariasi pada metode kultur botol berputar (a modified roller bottle culture) yang telah dimodifikasi dibandingkan dengan kultur cair yang dikocok atau kultur cair pada botol yang berputar (Yan et al, 2002).

Produksi senyawa antimikroba oleh bakteri laut dapat juga diinduksi oleh keberadaan bakteri darat yang hidup atau telah mati (Mearns-Spragg et al, 1998). Dua belas dari 16 bakteri epibiotik dari alga dan invertebrata menunjukan peningkatan aktivitas antimikroba terhadap S. aureus, E. coli, Pseudomonas aeruginosa setelah dipaparkan ke bakteri daratan yang hidup.

\section{KESIMPULAN}

Mikroba laut merupakan salah satu penghasil metabolit sekunder yang cukup menjanjikan. Beberapa kendala yang dialami pada proses kultivasi di laboratorium adalah tidak dihasilkannya metabolit sekunder. Ada beberapa upaya yang dapat dilakukan. Pertama, media yang digunakan dalam proses kultivasi divariasikan baik jenis maupun konsentrasi. Kedua, media yang digunakan ditambahkan prekursor metabolit sekunder seperti asam amino dan karbohidrat. Ketiga, proses kultivasi diusahakan mirip dengan keadaan di alam seperti pada proses kultivasi tidak dilakukan pengocokan atau modifikasi bioreaktor dengan menggunakan membran semipermeabel.

\section{UCAPAN TERIMA KASIH}


Penulis mengucapkan terima kasih kepada Bapak Sutarman Gafar, Fakultas Pertanian Universitas Tanjungpura atas kritikan dan saran pada artikel ini.

\section{DAFTAR PUSTAKA}

Amstrong, E. ,Yan, L., Boud, K.G., Wright, P.C, \& Burgess, J.G. 2001. The symbiotic role of marine microbes on living surfaces. Hydrobiologia 461:37-40.

Barry, K.J. \& Wainwright, N.R. 1997. Biosynthetic induction of a secondary metabolites by a marine bacterum under nutritional stress: potential role of the incomplete oxidation of an organic acid. Bioll Bull 193:274-275.

Bibb, M.J. 2005. Regulation of secondary metabolism in streptomycetes. Curr Opin Microbiol 8: 208-215.

Bruhn, J.B., Nielsen, K.F., Hjelm, M., Hansen, M., Bresciani, J., Schulz, S. \& Gram, L. 2005. Ecology, inhibitory activity, and morphogenesis of a marine antagonistic bacterium belonging to the roseobacter clade. Appl Microbiol Environ 71: 7263-7270.

Burgess, J.G. Jordan, E.M. Bregu, M. Mearns-Spragg, A. \& Boyd, K.G. 1999. Microbial antagonism: a neglected avenue of natural product research. J Biotechnol 70:27-32.

Chakraburtty, R. \& Bibb, M.J. 1997. The ppGpp Synthetase gene (relA) of Streptomyces coelicolor A3(2) plays a conditional role in antibiotic production and morphological differentiation. J Bacteriol 179: 5854-5861.

Chelossi, E., Milanese, M., Milano, A., Pronzato, R. \& Riccardi, G. 2004, Characterisation and antimicrobial activity of epibiotic bacteria from Petrosia ficiformis (porifera demosponsiae). J Exp Mar Biol Ecol 309: 21-33.

Claire, A.S. Rittschof, D. Gerhart, D.J. Hooper, I.R. \& Bonaventura, J. 1999. Anti-settlement and narcotic action of analogues of diterpene marine natural product antifoulant from octocarals. Mar Biotechnol 1: 427-436.

El-Sayed, A.K., Hothersall, J. \& Thomas, C.M. 2001. Quorum sensing-dependent regulation of biosynthesis of the polyketide antibiotic mupirocin in Pseudomonas fluorescens NCIMB 10586. Microbiol 147: 2127-2139.

Gonzalez, J.E \& Marketon, M.M. 2003. Quorum sensing in Nitrogen-Fixing Rhizobia. Microbiol Mol Biol Rev 67: 574592.

Gudbjarnason, S. 1999. Bioactive Marine Natural Product. Rit Fiskideilar 16:107-110.

Gutterson, N. Ziegle, J.S., Warren, G.W. \& Layton, T.J. 1988. Genetic determinants for catabolite induction of antibiotic biosynthesis in Pseudomonas fluorescens HV37a. J Bacteriol 170: 380-385.

Horinouchi, S., \& Beppu, T. 1992. Autoregulatory factors and communication in actinomycetes. Annu Rev Microbiol 46 : 377-398.
Kokare, C.R., Mahadik, K.R., Kadam, S.S. \& Chopade, B.S. 2004. Isolation, characterization and antimicrobial activity of marine halophilic Actinopolyspora species $\mathrm{AH} 1$ from the west coast of India. Curr Sci 86:593-597.

Long, R.A. \& Azam, F. 2001. Antagonistic Interactions among marine pelagic bacteria. Appl Environ Microbiol 67: 49754983.

Martin, J.F. 2004. Phosphate control of the biosynthesis of antibiotics and other secondary metabolites is mediated by the PhoR-PhoP System: an Unfinished Story. J. Bacteriol 186 (16): 5197-5201.

Muller, W.E.G., Schroder, H.J. \& Wiens, M. 2004. Approaches for a sustainable exploitation of biodiversity (secondary metabolites ans biomaterials from sponses) in traditional and modern biomedical prospecting:part ii-the benefits. eCAM 1:133-144.

Okami, Y. 1982. Potential use of marine microorganisms for antibiotics and enzyme production. Pure \& Appl Chem 54:1951-1962.

Prochnow, A.M., Evans, F., Saludes, D.D., Stelzer, S., Egan, S., James, S., Webb, J.S. \& Kjelleberg, S. 2004. Biofilm development and cell death in the marine bacterium Pseudoalteromonas tunicate. Appl Environ Microbiol 70 : 3232-3238.

Schroder, H.C., Ushijima, H., Krasko, A., Gamulin, V., Shutze, J. \& Muller, I.M. 2003. Emergence and disappearance of an immun molecule, an antimicrobial lectin, in basal metazoa: the achylectin family. J Biol Chem 278 32810-32817

Shiba, T. \& Taga, N. 1980. Heterotrophic bacteria attached to seaweeds. Journal of Experimental Marine Biology and Ecology. 47:251-258.

Tabarez, M.R. 2005. Discovery of the new antimicrobial compound 7-0-malonyl macrolactin a. Dissertation Van Der Gemeinsamen Naturwissenschaftlichen Fakultat. Jerman: Universitat Carolo-Wilhelmina.

Thakur, N.L., Hensschel, U., Krasko, A., Anil, A.C. \& Muller, W.E.G. 2003. Antibcterial activity of the sponse suberites domuncula and its primmorphs: potential basis for chemical defense. Aquatic Microbiol Ecol 31: 77-83.

Wiens, M., Luckas, B., Brummer, F., Ammar, M.S.A., Steffen, R. \& Batel, R. 2003. Okadaic acid: a potential defense molecule for the sponse Suberites domuncula. Mar Biol 142: 213-223.

Yan, L., Boyd, K.G. \& Burgess, J.G. 2002. Surface attachment induced production of antimicrobial compounds by marine epiphytic bacteria using modified roller bottle cultivation. Mar Biotecnol 4: 356-366.

Yan, L., Boyd, K.G., Adams, D.R. \& Burgess, J.G. 2003. Biofilmspecific cross species induction of antimicrobial compounds in bacilli. Appl Environ Microbiol 69: 3719-3727.

Zheng, L., Chen, H., Han, X., Lin, W. \& Yan, X. 2005. Antimicrobial screening and active compound isolation from marine bacterium NJ6-3-1 associated with the sponse Hymeniacidon perleve. World journal of Microbiology \& Biotechnology 21:201-206. 